Forsythe, D.E., Hess, D.J. (2002) Editor's Introduction. In: Studying Those Who Study Us: An Anthropologist in the World of Artificial Intelligence. Stanford University Press.

McDonald, S.M. et al. (2017) From Principle to Practice: Humanitarian Innovation and Experimentation. Norwegian Centre for Humanitarian Studies, December 22.

Obrecht, A. (2017) Evaluating Humanitarian Innovation. HIF-ALNAP Working Paper.

Ramalingam, B. et al. (2015) Strengthening the Humanitarian Innovation Ecosystem. www.brighton.ac.uk.

RobotWorx (2018) The Fourth Industrial Revolution Is Among Us. www.robots.com.

Sandvik, K.B. (2017) Now Is the Time to Deliver: Looking for Humanitarian Innovation's

Theory of Change. Journal of International Humanitarian Action, 2(1): 1-11.

Scriven, K. (2016) Humanitarian Innovation and the Art of the Possible. ODI H PN.

UNHCR (United Nations High Commissioner for Refugees) (2015) What Is Bottom-up Innovation? UN HCR Innovation (blog).

WeRobotics (2018) WeRobotics. Robotics for the Benefit of All. https://werobotics.org.

\title{
International Cooperation
}

International cooperation is a necessary element of humanitarian action and has been integral to humanitarian aid from its earliest beginnings. International cooperation can take many forms, be carried out between a large number of actors, and take place on different levels (El Taraboulsi et al. 2016). Cooperation does not necessarily involve state authorities. Depending on the context within which humanitarian aid is delivered, it may take place via, for example, a partnership between a small non-governmental organization (NGO) located in the Global South and a large NGO in the Global North. It may involve militias, private businesses, donors, NGO field staff, NGO headquarters, and the head of a village or a ministry. International cooperation is carried out both within complex, high-level diplomatic meetings and day-to-day interactions between, for example, expatriate and national staff in the field.

In the context of large-scale humanitarian emergencies that involve a number of different actors, international cooperation happens on a multitude of scales. For example, while the European Union's Emergency Response Coordination Center responds to a request from the disaster-affected country's civil protection authorities (European Commission 2019), the United Nations High Commissioner for Refugees (UNHCR) may be searching for implementing partners among national NGOs, and the International Committee of the Red Cross may be negotiating access with an armed group (Janmyr 2018). At the 
same time, the director of a national NGO may be responding to a call for projects by a specific NGO consortium that is helping her understand specific donor requirements. Thus, international cooperation takes place between aid providers and host states and societies, but also among aid providers from different countries.

The reasons for international cooperation are similarly varied. First, international cooperation ensures that providers of foreign aid have a legal basis for their presence abroad and are present at the request of host-state authorities. Secondly, cooperation is required to ensure an effective coordination between a large number of multinational aid providers and host state and society. Thirdly, cooperation is needed to agree on approaches to aid delivery that are acceptable to all stakeholders involved in the aid effort (Di Iorio and Zeuthen 2011). International cooperation can take place around questions of resources (e.g. when host states provide land for refugee camps built by UNHCR ), of access (e.g. when armed actors agree to ceasefires to allow aid into conflict zones), and also questions of cultural or political interests. As a bedrock of humanitarian aid, international cooperation occurs throughout and on all levels of the aid delivery process. Yet it is constantly subject to challenges related to, for example, unequal power relations within the international system, coercive measures implemented by powerful state actors, power imbalances, or the right to reject aid. When foreign actors deliver aid abroad without the cooperation of the host country, this mostly has negative results: aid delivery may become chaotic, and at worst it may be considered a hostile act.

\section{Sophia Hoffmann}

\section{References}

Di Iorio, E., Zeuthen, M. (2011) The Benefits of Engaging and Building Trust with a Reluctant Government: The Experience of Community Center for Iraqis in Syria. Iraq Study Group. Middle East Institute.

El Taraboulsi, S. et al. (2016) Regional Organisations and Humanitarian Action: Rethinking Regional Engagement. Overseas Development Institute.

European Commission (2019) European Civil Protection Mechanism, Factsheet. https:// ec.europa.eu.

Janmyr, M. (2018) UNHCR and the Syrian Refugee Response: Negotiating Status and Registration in Lebanon. The International Journal of Human Rights, 22(3): 393-419. 